\title{
Allocation of Greenhouse Gas Emissions Using the Fairness Principle: A Multi-Country Analysis
}

\author{
Laura Rodríguez-Fernández ${ }^{1, *(\mathbb{C})}$, Ana Belén Fernández Carvajal ${ }^{2}$ (I) and María Bujidos-Casado ${ }^{3}$ \\ 1 Department of Business Economics and Accounting, National Distance Education University (UNED), \\ 28040 Madrid, Spain \\ 2 Economy Department, University of León, 24006 León, Spain; afernc@unileon.es \\ 3 Business Organization Department, National Distance Education University (UNED), 28040 Madrid, Spain; \\ mbujidos@cee.uned.es \\ * Correspondence: lrodriguezf@cee.uned.es
}

Received: 3 June 2020; Accepted: 15 July 2020; Published: 20 July 2020

check for updates

\begin{abstract}
This study presents an analysis of the allocation of greenhouse gas emissions based on a comparison of criteria for 66 countries and fairness-based indicators. The academic literature contains very few broad multi-country studies. The large sample of countries included in our analysis has allowed us to make a more comprehensive, holistic comparison than other studies with similar characteristics. The United States and China must make the greatest effort to fight climate change worldwide, but all countries have a responsibility, including some that are not usually analyzed in this type of research.
\end{abstract}

Keywords: emission reduction; greenhouse gases; climate change; carbon emission allocation; fairness principle

\section{Introduction}

Burning fossil fuels has led to an increase in greenhouse gas (GHG) emissions and ushered in a global energy transition [1-4], which in turn has sparked a profound and growing interest in reducing these emissions due to their devastating effect on our planet. Emission reduction has been the focus of the discussions held in the latest climate summits, particularly the 2015 Paris Summit. The global agreement on climate change signed in Paris in 2015 set out a framework for limiting global warming to well below $2{ }^{\circ} \mathrm{C}$ compared to pre-industrial levels $[5,6]$. The response to this problem was in turn formalized in each state's commitments to reduce GHG emissions in the framework of the Paris Agreement [7,8]. However, these commitments are incongruous on two levels: first, they are voluntary $[9,10]$; second, if all were met, the average temperature would increase by $3{ }^{\circ} \mathrm{C}[10,11]$. In Conference of the Parties, COP25, in Madrid, progress was checked against outstanding rules, an assessment of loss and damage was made as per the Warsaw International Mechanism, and commitments were made toward financial support and capacity building [12], but the decision to withdraw from the Paris accord limited the summit success.

Finding the best way to share global emission reductions among all countries is a top priority for researchers [13], given the need to limit the increase in GHG emissions in carbon budgets [14]. In fact, as detailed in the following section, the allocation of emission quotas has received considerable attention in the academic literature, but the scope of the analysis has so far been restricted to limited groups of companies and countries.

Therefore, in this article we propose various GHG emission allocation schemes for a broader sample of countries based on different criteria. The aim of the study is to determine and compare the responsibility of each country studied using various fairness-based indicators. Several authors 
have compared burden sharing rules at the country level. However, these studies have used other objectives, other allocation methods, or other samples (see, for example, [15-19]). This article, inspired by the proposals presented by Ringius et al. [20] and Winkler et al. [21], is the first of its kind to study the allocation of responsibilities in a larger group of countries.

The rest of the document is structured as follows: Section 2 describes the methodology of the different allocation criteria used. Next, Section 3 presents the different allocation results according to the criteria used. Finally, Section 4 establishes the most relevant conclusions.

\section{Brief Literature Review}

Research into carbon dioxide emissions allocation and convergence is a fertile field that includes literature reviews and meta-analyses, such as Pettersson et al. [22], Zhou and Wang [23], Acar et al. [7], and Payne [24], or more recently, Duro, Giménez-Gómez, and Vilella [25]. The academic literature also includes studies that have addressed emission allocation at the company level, particularly through the game theory approach [26-29] and linear programming models such as data envelope analysis [30-32].

Since the 1990s, a considerable body of literature has focused on emission allocations in each country $[23,33]$. In this corpus, emissions have variously been allocated by zoning, to a small group of countries [20,21,34-36], or by limiting the research to a single country [37-39]. Studies on allocations in China ([40,41], for example), Chinese regions [42-46], Chinese cities [8], and Chinese sectors and industries $[39,43]$ are particularly abundant. Other studies have focused on groups of countries, such as North America [44-46], Latin America [45], or three high-emission Asian countries-China, Japan, and South Korea (ROK)—by Ma, Cai, Ye, and Gu [47].

In the European Union (EU), since its inception in 2005, the EU Emissions Trading Scheme (EU ETS) has limited the annual aggregate emissions of carbon dioxide by allocating a certain amount of pollution permits. The available evidence [48] suggests that the EU ETS has had a robust negative impact on the carbon emissions, without strong detrimental effects in economic performance. In terms of financial performance of firms, Oestreich and Tsiakas [49] report a large and statistically significant carbon premium in stock returns. However, studies on Europe [50-52] and the USA $[53,54]$ are less common, and those presenting a more global, holistic perspective, such as ours, are particularly scarce $[55,56]$.

The academic literature includes various methods or approaches using several different allocation criteria based on two principles: efficiency, namely the economic efficiency of restricting emissions [23], and fairness, namely the fair distribution of emissions liability [20]. Each allocation criterion can be implemented using different indicators [23,37]. According to the latter authors, composite and above all simple indicators are the most common methods used. The indicator approach is almost compulsory, but "it is difficult to reach a consensus on the indicator used since the variation in the allocation results by different indicator methods is rather large" [23]. Therefore, it is probably advisable to use several indicators to enrich the comparison and strengthen the analysis.

\section{Methodology and Data}

The main obstacle to achieving the global energy transition lies in meeting the Paris Agreement target to reduce global GHG emissions based on the fairness principle. $\mathrm{CO}_{2}$ allocation-based methods are an appropriate conceptual tool for distributing emission of this gas [20] because they are transparent and specifiable with perfect certainty [37].

In order to estimate the capacity to mitigate climate change, we based our analysis on studies that incorporate the fairness principle and the indicator method, which is the most appropriate approach to use when applying the fairness principle [23].

The global emissions budget differs according to whether reductions, growth, or rights are allocated [21]. Since the objective of this study is to allocate reductions, we assume that global emissions will return to 1990 levels by 2050 (target year for the Paris Agreement), which is a 54\% reduction. For the empirical study, we used BP's emissions data and the World Bank's population and 
Gross Domestic Product (GDP) data to allocate reductions to 66 countries, representing just over $90 \%$ of the global total, through to 2050.

\subsection{Simple Indicator}

Given the criteria and indicators shown in Table 1, we developed various emission distribution schemes using the formulas put forward by Ringius et al. [20] and Winkler et al. [23].

In the first scheme we use a simple indicator to assess the allocation of emissions between sample countries. A simple indicator can be described as a quantitative or qualitative measure derived from a series of observed facts that can provide the relative position of a country, for example, in any given area [57].

Table 1. Selected criteria and indicators.

\begin{tabular}{cccc}
\hline Allocation Criteria & Interpretation & Indicator & Unit \\
\hline $\begin{array}{c}\text { Historical responsibility: } \\
\text { This criterion is also } \\
\text { Prown as the Brazilian }\end{array}$ & $\begin{array}{c}\text { Countries with most historical } \\
\text { emissions must achieve } \\
\text { greater reductions }\end{array}$ & $\begin{array}{c}\text { Cumulative emissions } \\
\text { between 1965 and 2016 }\end{array}$ & Tonnes of $\mathrm{CO}_{2}$ \\
\hline Egalitarian & $\begin{array}{c}\text { All countries have the same } \\
\text { right to use the atmosphere }\end{array}$ & Population & $\begin{array}{c}\text { No. of } \\
\text { inhabitants }\end{array}$ \\
\hline Ability to pay & $\begin{array}{c}\text { Rich countries must shoulder } \\
\text { more reduction burdens }\end{array}$ & GDP $\$$ \\
Sovereignty & $\begin{array}{c}\text { Nations with more emissions } \\
\text { at present must take on a } \\
\text { greater reduction burden }\end{array}$ & Current emissions & Tonnes of $\mathrm{CO}_{2}$ \\
\hline
\end{tabular}

Source: Author, Ringius et al. [20], and Zhou and Wang [23].

\subsection{Historical Responsibility Criterion (HR)}

First, we used the HR criterion between 1965 and 2016 to estimate the emission reduction quota for each country according to our global emission reduction budget. This criterion indicates that emission reduction is allocated according to the level of accumulated emissions over a period of time [23]. Ridgley [34] used several criteria, including HR (in terms of global and per capita emissions), to distribute the burden of emissions among 11 world regions (Africa, China, Latin America, the Middle East/North Africa, Eastern and Western OECD (Organization for Economic Co-operation and Development), the United States, South Asia, Southeast Asia, and the former USSR). Their results indicate that the greatest burden of responsibility lies with the United States. Later, Winkler et al. [16] applied this and other criteria to six developing countries (China, India, Brazil, South Africa, Argentina, and Nigeria), and concluded that in absolute terms the largest emissions reduction quota should be allocated to China.

In our case, the participation of country $i$ in the distribution of emissions reduction $\left(X_{i}\right)$ is calculated using the following formula:

$$
X_{i}=\text { Global reduction budget } \times \begin{aligned}
& \text { Historical emissions as a percentage of the world total } \\
& \text { between 1965-2016. }
\end{aligned}
$$

\subsection{Ability to Pay Criterion}

Secondly, we use the ability to pay criterion (according to this criterion, the emission reduction allocation is linked to the country's wealth [34]) The GDP of country $i$ as a percentage of total world GDP in 2016 is a simple indicator to mitigate climate change. According to this criterion, the richest countries would have to shoulder a greater burden than poor countries when it comes to reducing emissions [23]. On a regional scale, Rose and Zhang [37] and Zhou et al. [38] used this criterion to assign $\mathrm{CO}_{2}$ emission permits to different regions of the United States and China, respectively. The same criterion was also used in the aforementioned studies by Ridgley [34] and Winkler et al. [21] and yielded 
the same results after applying the HR criteria: in the first case, the largest reductions correspond to the United States, and in the second to China. In this document, the participation of country $i$ in the distribution of emissions reduction $(\mathrm{X} i)$ is calculated using the following formula:

$$
X_{i}=\text { Global reduction budget } \times \text { GDP US } \$ \text { of country } i \text { as a percentage of total world GDP (2016). }
$$

\subsection{Composite Indicator}

In the first schemes we use a composite indicator to distribute emissions reductions among a sample of countries. The distribution of emission reductions has been made on the basis of the countries available in the BP yearbook [59], as it includes information from a broad set of regions and countries, as well as emissions data after 1965. A synthetic or composite indicator is an aggregate index of simple indicators and is obtained by weighting these indicators according to their relative importance in the index. Thus, while a simple indicator refers to a single dimension or magnitude, a composite indicator refers to several multidimensional concepts [57].

In this study, we used the composite indicator method based on one of the proposals made by Ringius et al. [20], who used three specific formulas each with a group of indicators, to allocate GHG emission reductions to some OECD member countries (except Australia, Austria, Belgium, Canada, Denmark, Finland, France, Germany, Greece, Ireland, Italy, Japan, Luxembourg, The Netherlands, New Zealand, Norway, Portugal, Spain, Sweden, Switzerland, Turkey, the United Kingdom, and the United States). Using Formula $2\left(X_{i}=\left\{w E x E_{i}+w P x P_{i}+w G x G_{i}\right\}\right)$, they found that the greatest reduction in emissions as a percentage of the total reduction of all OECD countries would correspond to the United States. In this document, the participation of country $i$ in the distribution of emissions reduction $(X i)$ is calculated from an index based on this formula. Thus, two general GHG emission reduction allocation schemes are analyzed using the composite indicator method.

The first scheme (Formula 1) obeys the four criteria mentioned in Table 1: egalitarianism (population), ability to pay (GDP), current responsibility (current emissions), and historical responsibility (emissions accumulated between 1965 and 2016). In our case, $X_{i}$ is the percentage participation of country $i$ in the distribution of emissions reduction. $E_{i}$ is the $\mathrm{CO}_{2}$ emissions of country $i$ as a percentage of the world total in 2016. $E H_{i}$ is the cumulative $\mathrm{CO}_{2}$ emissions of country $i$ as a percentage of the world total between 1965 and 2016. $P_{i}$ is the population of country $i$ as a percentage of the world total in 2016, and $G_{i}$ is the US\$ GDP of country $i$ as a percentage of the world total. In this study, a single aggregation method has been used: each indicator is weighted at 0.25 and considered to be equally relevant.

$$
X_{i}=\left\{w E x E_{i}+w E H x E H_{i}+w P x P_{i}+w G x G_{i}\right\} \times \text { Overall reduction budget }
$$

The second scheme (Equation (2) obeys three criteria: egalitarianism (population), ability to pay (GDP), and current responsibility (current emissions). As in the previous case, $X_{i}$ is the percentage participation of country $i$ in the distribution of emissions reduction. $E_{i}$ is the $\mathrm{CO}_{2}$ emissions of country $i$ as a percentage of the world total in 2016. $P i$ is the population of country $i$ as a percentage of the world total in 2016. Gi is the US\$ GDP of country $i$ as a percentage of the world total. The sum of weights $(w)$ is equal to 1 . In this study, a single aggregation method has been used: each indicator is weighted at 0.33 and considered to be equally relevant.

$$
X_{i}=\left\{w E x E_{i}+w P x P_{i}+w G x G_{i}\right\} \times \text { Overall reduction budget }
$$

\section{Results}

Table 2 summarizes the emission allocation for the 66 countries studied according to the Formulas 1 and 2. Both formulas coincide in the top 10 countries that must further reduce their emissions: five of them belong to the OECD (the United States, Japan, Germany, United Kingdom, and France), one of them is a candidate for accession (Russia), and the rest are acceding countries with which the organization maintains enhanced cooperation (for example, China and India). 
Table 2. Reductions allocated according to Formula 1 and 2.

\begin{tabular}{|c|c|c|c|c|c|}
\hline \multirow{2}{*}{ Countries/Areas } & \multicolumn{2}{|c|}{ Formula 1} & \multirow{2}{*}{ Countries/Areas } & \multicolumn{2}{|c|}{ Formula 2} \\
\hline & $(\mathrm{Mt} \mathrm{CO})_{2}$ & (\% of Total) & & $\left(\mathrm{Mt} \mathrm{CO}_{2}\right)$ & (\% of Total) \\
\hline China & 2251.13 & $19.02 \%$ & China & 2365.70 & $19.99 \%$ \\
\hline US & 2019.82 & $17.07 \%$ & US & 1753.44 & $14.82 \%$ \\
\hline India & 920.51 & $7.78 \%$ & India & 1076.68 & $9.10 \%$ \\
\hline Japan & 487.29 & $4.12 \%$ & Japan & 460.44 & $3.89 \%$ \\
\hline Russian Federation & 380.60 & $3.22 \%$ & Russian Federation & 315.86 & $2.67 \%$ \\
\hline Germany & 359.99 & $3.04 \%$ & Germany & 311.30 & $2.63 \%$ \\
\hline United Kingdom & 245.02 & $2.07 \%$ & Brazil & 254.94 & $2.15 \%$ \\
\hline Brazil & 225.15 & $1.90 \%$ & Indonesia & 247.09 & $2.09 \%$ \\
\hline Indonesia & 213.14 & $1.80 \%$ & United Kingdom & 219.94 & $1.86 \%$ \\
\hline France & 203.00 & $1.72 \%$ & France & 198.97 & $1.68 \%$ \\
\hline Canada & 181.82 & $1.54 \%$ & South Korea & 176.92 & $1.50 \%$ \\
\hline Italy & 176.93 & $1.50 \%$ & Mexico & 175.76 & $1.49 \%$ \\
\hline South Korea & 174.42 & $1.47 \%$ & Italy & 166.86 & $1.41 \%$ \\
\hline Mexico & 170.26 & $1.44 \%$ & Canada & 159.41 & $1.35 \%$ \\
\hline Iran & 137.94 & $1.17 \%$ & Pakistan & 138.26 & $1.17 \%$ \\
\hline Australia & 130.25 & $1.10 \%$ & Iran & 137.40 & $1.16 \%$ \\
\hline Saudi Arabia & 125.39 & $1.06 \%$ & Turkey & 128.56 & $1.09 \%$ \\
\hline Spain & 122.47 & $1.03 \%$ & Saudi Arabia & 122.85 & $1.04 \%$ \\
\hline Turkey & 117.86 & $1.00 \%$ & Australia & 122.44 & $1.03 \%$ \\
\hline Pakistan & 115.29 & $0.97 \%$ & Spain & 120.86 & $1.02 \%$ \\
\hline South Africa & 110.17 & $0.93 \%$ & Bangladesh & 106.08 & $0.90 \%$ \\
\hline Poland & 106.89 & $0.90 \%$ & South Africa & 94.25 & $0.80 \%$ \\
\hline Thailand & 85.11 & $0.72 \%$ & Egypt & 93.12 & $0.79 \%$ \\
\hline Egypt & 83.35 & $0.70 \%$ & Thailand & 91.20 & $0.77 \%$ \\
\hline Bangladesh & 83.28 & $0.70 \%$ & Philippines & 83.91 & $0.71 \%$ \\
\hline The Netherlands & 82.04 & $0.69 \%$ & Poland & 79.10 & $0.67 \%$ \\
\hline Ukraine & 73.26 & $0.62 \%$ & Vietnam & 78.72 & $0.67 \%$ \\
\hline Argentina & 71.86 & $0.61 \%$ & Argentina & 73.79 & $0.62 \%$ \\
\hline Philippines & 70.28 & $0.59 \%$ & The Netherlands & 73.77 & $0.62 \%$ \\
\hline Vietnam & 65.96 & $0.56 \%$ & Malaysia & 62.65 & $0.53 \%$ \\
\hline Malaysia & 59.64 & $0.50 \%$ & Venezuela & 59.20 & $0.50 \%$ \\
\hline Venezuela & 59.39 & $0.50 \%$ & United Arab Emirates & 56.46 & $0.48 \%$ \\
\hline United Arab Emirates & 56.02 & $0.47 \%$ & Ukraine & 52.59 & $0.44 \%$ \\
\hline Belgium & 50.85 & $0.43 \%$ & Colombia & 50.46 & $0.43 \%$ \\
\hline Kazakhstan & 45.81 & $0.39 \%$ & Algeria & 45.38 & $0.38 \%$ \\
\hline Singapore & 45.28 & $0.38 \%$ & Singapore & 44.93 & $0.38 \%$ \\
\hline Colombia & 44.78 & $0.38 \%$ & Belgium & 44.11 & $0.37 \%$ \\
\hline Algeria & 42.40 & $0.36 \%$ & Switzerland & 43.04 & $0.36 \%$ \\
\hline Czech Republic & 41.44 & $0.35 \%$ & Kazakhstan & 40.61 & $0.34 \%$ \\
\hline Switzerland & 38.08 & $0.32 \%$ & Sweden & 37.36 & $0.32 \%$ \\
\hline Romania & 37.82 & $0.32 \%$ & Uzbekistan & 33.84 & $0.29 \%$ \\
\hline Sweden & 37.33 & $0.32 \%$ & Chile & 33.46 & $0.28 \%$ \\
\hline Uzbekistan & 34.87 & $0.29 \%$ & Peru & 32.81 & $0.28 \%$ \\
\hline Austria & 32.07 & $0.27 \%$ & Austria & 31.99 & $0.27 \%$ \\
\hline Chile & 30.98 & $0.26 \%$ & China Hong Kong SAR & 31.18 & $0.26 \%$ \\
\hline China Hong Kong & 29.75 & $0.25 \%$ & Israel & 29.21 & $0.25 \%$ \\
\hline Peru & 28.17 & $0.24 \%$ & Romania & 28.08 & $0.24 \%$ \\
\hline Israel & 27.72 & $0.23 \%$ & Czech Republic & 27.91 & $0.24 \%$ \\
\hline Greece & 27.29 & $0.23 \%$ & Norway & 26.24 & $0.22 \%$ \\
\hline Denmark & 25.45 & $0.22 \%$ & Greece & 23.46 & $0.20 \%$ \\
\hline Norway & 24.11 & $0.20 \%$ & Denmark & 23.36 & $0.20 \%$ \\
\hline Finland & 22.30 & $0.19 \%$ & Ireland & 22.70 & $0.19 \%$ \\
\hline Portugal & 22.09 & $0.19 \%$ & Portugal & 22.19 & $0.19 \%$ \\
\hline
\end{tabular}


Table 2. Cont.

\begin{tabular}{|c|c|c|c|c|c|}
\hline \multirow{2}{*}{ Countries/Areas } & \multicolumn{2}{|c|}{ Formula 1} & \multirow{2}{*}{ Countries/Areas } & \multicolumn{2}{|c|}{ Formula 2} \\
\hline & $\left.(\mathrm{Mt} \mathrm{CO})_{2}\right)$ & (\% of Total) & & $\left.(\mathrm{Mt} \mathrm{CO})_{2}\right)$ & (\% of Total) \\
\hline Ireland & 21.63 & $0.18 \%$ & Qatar & 21.67 & $0.18 \%$ \\
\hline Kuwait & 21.56 & $0.18 \%$ & Kuwait & 20.52 & $0.17 \%$ \\
\hline Hungary & 21.43 & $0.18 \%$ & Finland & 20.05 & $0.17 \%$ \\
\hline Qatar & 20.03 & $0.17 \%$ & Ecuador & 17.76 & $0.15 \%$ \\
\hline Bulgaria & 16.87 & $0.14 \%$ & Hungary & 17.06 & $0.14 \%$ \\
\hline Belarus & 15.91 & $0.13 \%$ & New Zealand & 16.22 & $0.14 \%$ \\
\hline New Zealand & 15.84 & $0.13 \%$ & Turkmenistan & 14.89 & $0.13 \%$ \\
\hline Ecuador & 15.59 & $0.13 \%$ & Belarus & 13.69 & $0.12 \%$ \\
\hline Turkmenistan & 15.20 & $0.13 \%$ & Bulgaria & 11.65 & $0.10 \%$ \\
\hline Slovakia & 14.08 & $0.12 \%$ & Azerbaijan & 11.03 & $0.09 \%$ \\
\hline Azerbaijan & 11.31 & $0.10 \%$ & Slovakia & 11.00 & $0.09 \%$ \\
\hline Trinidad \& Tobago & 5.66 & $0.05 \%$ & Lithuania & 5.26 & $0.04 \%$ \\
\hline Lithuania & 5.48 & $0.05 \%$ & Trinidad \& Tobago & 4.89 & $0.04 \%$ \\
\hline OECD & 5053.04 & $42.70 \%$ & OECD & 4597.92 & $38.85 \%$ \\
\hline UE & 1700.52 & $14.37 \%$ & UE & 1523.58 & $12.87 \%$ \\
\hline No OECD & 6780.78 & $57.30 \%$ & No OECD & 7235.91 & $61.15 \%$ \\
\hline Total top 10 & 7305.64 & $61.74 \%$ & Total top 10 & 7204.38 & $60.88 \%$ \\
\hline Total considered & $10,654.69$ & $90.04 \%$ & Total considered & $10,516.54$ & $88.87 \%$ \\
\hline Rest & 1179.13 & $9.96 \%$ & Rest & 1317.28 & $11.13 \%$ \\
\hline Total World & $11,833.82$ & $100.00 \%$ & Total World & $11,833.82$ & $100.00 \%$ \\
\hline
\end{tabular}

Source: Author, using BP [59] and World Bank data [60].

Table 3 summarizes the allocation of emissions according to the HR criteria (Formula 3) for the five main $\mathrm{CO}_{2}$ emitters and the country groupings considered in this study. Based on our global reduction budget, the results confirm that the burden falls on OECD countries. This organization accounts for $53 \%$ of emissions that must be reduced; therefore, the greatest responsibility, according to the HR criterion, lies with developed countries. Furthermore, the countries made up of the G20 (G8 nations plus other recently industrialized countries), account for more than $81 \%$ of the total. On an individual level, the United States heads the list.

Table 3. Reductions allocated according to the HR criterion * (Formula 3).

\begin{tabular}{ccc}
\hline Countries/Areas & $\mathbf{( M t ~ C O}_{\mathbf{2}} \mathbf{)}$ & $\mathbf{( \% \text { del Total) }}$ \\
\hline US & 2765.83 & $23.37 \%$ \\
China & 1835.75 & $15.51 \%$ \\
Russian Federation & 565.24 & $4.78 \%$ \\
Japan & 553.86 & $4.68 \%$ \\
Germany & 496.61 & $4.20 \%$ \\
OECD & 6272.30 & $53.00 \%$ \\
No OECD & 5561.53 & $47.00 \%$ \\
North America & 3158.51 & $26.69 \%$ \\
South Central America & 328.37 & $2.77 \%$ \\
Africa & 238.35 & $2.01 \%$ \\
Europe and Eurasia & 3119.94 & $26.36 \%$ \\
Asia Pacific & 3603.47 & $30.45 \%$ \\
G8 & 5350.48 & $46.00 \%$ \\
G20 & 9691.08 & $81.54 \%$ \\
Total top 5 & 7605.59 & $52.54 \%$ \\
Total considered & $10,750.46$ & $90.85 \%$ \\
Rest & 1083.36 & $9.15 \%$ \\
Total World & $11,833.82$ & $100.00 \%$ \\
\hline
\end{tabular}

Source: Author, using BP data [59]. Note: The grouping of countries is detailed in Appendix A ${ }^{*}$ See the results of the 166 countries in Appendix B: Table A1. 
Taking only the ability to pay criterion into account (Formula 4), the OECD accounts for $62.76 \%$ of emissions that must be reduced to achieve the Paris target. In fact, the reduction quota allocated to the top five countries, which includes many OECD counties accounts for $53.93 \%$ of the world total (Table 4). Taking this criterion into account, it is observed that the difference between the US and China is greater than in comparison with the others. The high percentages of North America and the G-20 countries stand out.

Table 4. Reductions allocated according to the ability to pay criterion * (Formula 4).

\begin{tabular}{ccc}
\hline Countries/Areas & $\mathbf{( M t ~ C O}_{\mathbf{2}} \mathbf{)}$ & $\mathbf{( \% \text { of Total) }}$ \\
\hline US & 2905.80 & $24.56 \%$ \\
China & 1747.30 & $14.77 \%$ \\
Russian Federation & 771.28 & $6.52 \%$ \\
Japan & 542.61 & $4.59 \%$ \\
Germany & 413.13 & $3.49 \%$ \\
OECD & 7426.95 & $62.76 \%$ \\
No OECD & 4406.87 & $37.24 \%$ \\
North America & 3307.82 & $27.95 \%$ \\
and Central America & 732.82 & $6.19 \%$ \\
Africa & 122.28 & $1.04 \%$ \\
Europe and Eurasia & 3097.68 & $26.18 \%$ \\
Asia Pacific & 382.29 & $32.28 \%$ \\
G8 & 3344.67 & $48.58 \%$ \\
G20 & 7749.23 & $85.79 \%$ \\
Total top 5 & 7926.86 & $53.93 \%$ \\
Total considered & $11,229.57$ & $94.89 \%$ \\
Rest & 604.25 & $5.11 \%$ \\
Total World & $11,833.82$ & $100.00 \%$ \\
\hline
\end{tabular}

Source: Author, using BP [50] and World Bank data [51]. * See the results of the 166 countries in Appendix B: Table A2.

The results of the four emission reduction allocation formulas for the United States and China, as the two main emitters, and the groupings of countries analyzed in this document are summarized in Table 5. A comparison between the HR and ability to pay criteria shows that the list is headed to a large extent by the same countries, although the distribution of emission reduction quotas differs: under the second (ability to pay) criterion, the most developed countries (OECD) have to make more significant reductions. It is important to note that, under the criteria of historical responsibility and ability to pay (with a similar participation in the distribution), the United States has to make the greatest commitment to mitigating climate change. It also ranks second according to the fairness criterion measured by the composite indicator approach. China has to make a greater effort, taking into account the HR criterion as well as India and the Russian Federation. On the other hand, Japan is more sensitive to the ability to pay criterion. This highlights that the non-OECD countries have a relatively high reduction in the criterion of historical responsibility that shows their greater participation in global cumulative emissions. Meanwhile, OECD countries have a greater goal of reducing the ability to pay criterion.

Table 5. Allocated emission reductions according to the different calculations ( $\%$ of the total).

\begin{tabular}{ccccc}
\hline Countries/Areas & Formula 1 & Formula 2 & Formula 3 & Formula 4 \\
\hline US & $19.02 \%$ & $14.82 \%$ & $23.37 \%$ & $24.56 \%$ \\
China & $17.07 \%$ & $19.99 \%$ & $15.51 \%$ & $14.77 \%$ \\
India & $7.78 \%$ & $9.10 \%$ & $3.54 \%$ & $2.98 \%$ \\
Japan & $4.12 \%$ & $3.89 \%$ & $4.68 \%$ & $6.52 \%$ \\
Russian Federation & $3.22 \%$ & $2.67 \%$ & $4.78 \%$ & $1.69 \%$ \\
OECD & $42.70 \%$ & $38.85 \%$ & $53.00 \%$ & $62.76 \%$ \\
No OECD & $57.30 \%$ & $61.15 \%$ & $47.00 \%$ & $37.24 \%$ \\
\hline
\end{tabular}




\section{Discussion and Conclusions}

The global agreement on climate changes signed in Paris in 2015 set out a framework for limiting global warming to well below $2{ }^{\circ} \mathrm{C}$ compared to pre-industrial levels. However, emissions have only increased since then [61] (Figure 1).

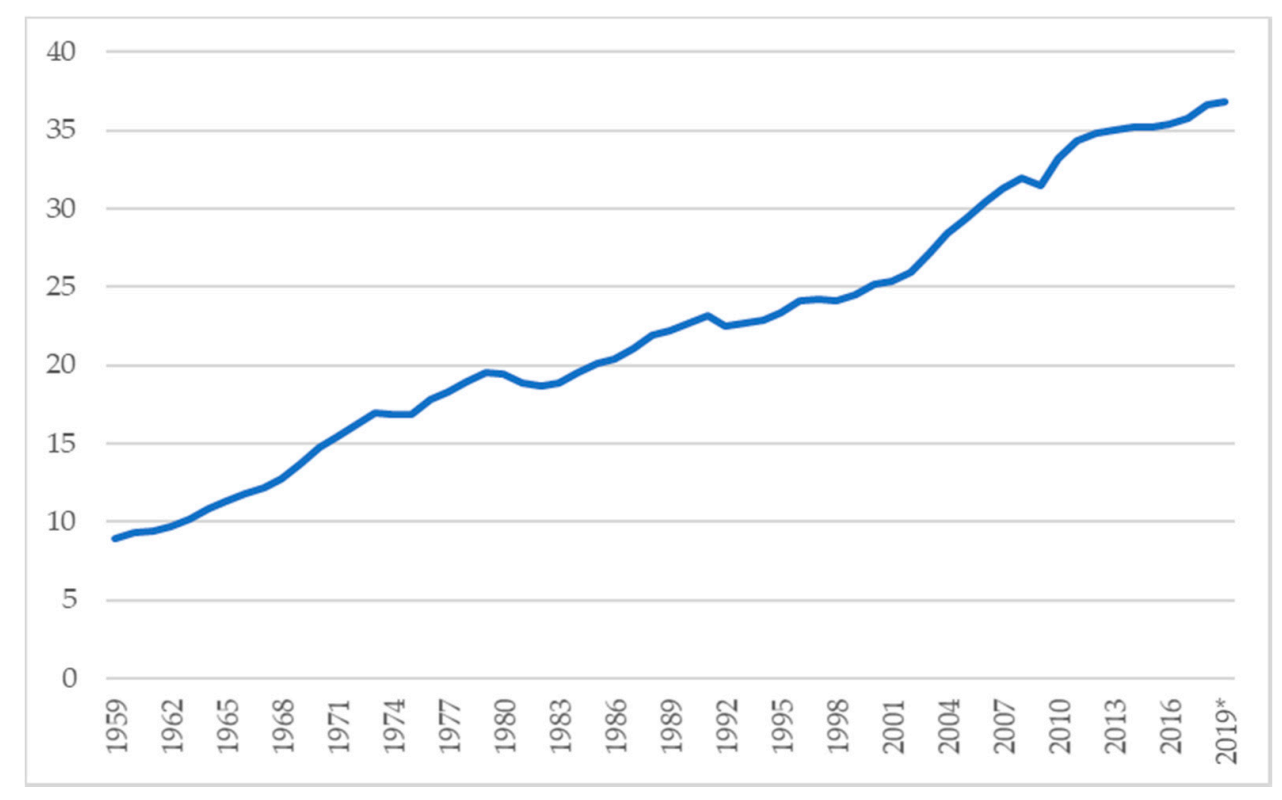

Figure 1. Evolution of global $\mathrm{CO}_{2}$ emissions from the use of fossil fuels and industrial activity. (Gt $\mathrm{CO}_{2}$ ). Source: Global Carbon Project [61]. * Forecast.

Our study confirms the findings of earlier authors. Under the criteria of historical responsibility and ability to pay, the United States has to make the greatest commitment to mitigating climate change [34]. Nevertheless, this leadership position is not echoed in its contribution to climate change literature, particularly compared to the number of Chinese studies published. Nevertheless, our analysis differs from previous studies $[20,21]$ insofar as it includes a broader sample of countries.

Our analysis of the responsibility of developed countries shows that according to the HR and ability to pay criteria, the OECD accounts for the highest percentage of emissions that need to be reduced to meet the Paris objective. This has important implications for the OECD as a whole, as it needs to make significant reductions in $\mathrm{CO}_{2}$ emissions to mitigate the problem of climate change. However, using the composite indicator, our results show that the greatest responsibility lies with non-OECD member states. Obviously, these results could change if a different weight is assigned to each indicator.

Although our results show the importance of distributing emissions reduction quotas, they also demonstrate the need for caution when distributing reductions according to composite indicators, and probably explain why many experts choose to use simple indicators.

Our analysis suggests that the United States and China are the greatest contaminators and have the greatest responsibility when it comes to reducing emissions, a situation that highlights the major impact that the United States' decision to abandon the Paris agreement in 2017 will have on climate change in the future. The United States might not reduce its emissions at all, and its decision to stop contributing to the Global Environment Fund will most likely hinder progress in meeting the Paris Agreement targets [62].

It is imperative that fossil fuel producing countries modify their business models to combat climate change, and all countries in general should realize that increasing the global share of clean energy in the energy consumption structure and restructuring industries would be an effective policy. Theoretical claim problem (a claim problem is a particular distribution problem in which the amount to be distributed, endowment $E$, is not enough to cover the agents' claims on it [20]) approaches are impracticable due to the absence of a supra-national authority-a social planner-with 
the capacity to propose a fair and egalitarian system for allocating resources based on different socially accepted principles [25], and allocation agreements that impose convergence would result in significant international income transfers. It is important to underline the responsibility of each government in achieving higher targets. In fact, the Paris Agreement places special value on voluntary contributions and national circumstances, but some studies have reported that the voluntary mitigation targets expressed in the Intended Nationally Determined Contributions are insufficient [55,63], which further enhances the need of discussing emission allowances of the countries. Our article informs policymakers of more countries about the importance of carbon emissions reduction in order to tackle environmental challenges and Nationally Determined Contributions. In particular for the European countries, the European Commission intends to propose, as part of the Green Deal, to increase the EU's 2030 target for greenhouse gas emission reductions to at least $-50 \%$ and towards $-55 \%$ compared to 1990 levels, in a responsible way. This should be an example to follow by the rest of the countries analyzed in our study

Companies that possess resources of extraordinary importance need to be involved in reducing emissions. They can play a major role in halting global GHG emissions and introducing international global warming policies [64,65]. Taking the Paris goal seriously also involves limiting the use of fossil resources and leaving a percentage of fossil fuel reserves underground [66], since the emissions generated by these fuels are associated with an increase in $\mathrm{CO}_{2}$ levels and global warming. Finally, let us not forget that the Paris Agreement also calls on all states, particularly the principle consumers, to reduce their consumption of fossil resources.

Our study is somewhat exploratory, given the large sample of countries studied, and this is its main limitation. However, it is the first analysis of such a large sample of countries, including some that are not usually analyzed in this type of research (i.e., Slovakia or Portugal). This broader comparison and our new results make an interesting contribution to the study of carbon emission quotas. A clear example of this is India, which in our study is always one of the top-ranking countries in the different indexes used but is not very often analyzed in the academic literature [67]. This also opens new avenues of research and encourages researchers to broaden their geographical approach to obtain more global, comprehensive results.

Author Contributions: L.R.-F., A.B.F.C. and M.B.-C. contributed equally to this work. All authors wrote, reviewed, and commented on the manuscript. All authors have read and agreed to the published version of the manuscript.

Funding: This research received no external funding.

Conflicts of Interest: The authors declare no conflict of interest.

\section{Appendix A. Country Groups Used in the Document}

- North America: US (excluding Puerto Rico), Canada, and Mexico.

- South and Central America: Caribbean (including Puerto Rico) and Central and South America.

- Europe: European members of the OECD plus Albania, Bosnia-Herzegovina, Bulgaria, Croatia, Cyprus, Former Yugoslav Republic of Macedonia, Gibraltar, Malta, Romania, Serbia and Montenegro, Slovenia.

- Former Soviet Union: Armenia, Azerbaijan, Belarus, Estonia, Georgia, Kazakhstan, Kyrgyzstan, Latvia, Lithuania, Moldova, Russian Federation, Tajikistan, Turkmenistan, Ukraine, Uzbekistan.

- Europe and Eurasia: All countries listed above under the headings Europe and the Former Soviet Union.

- Asia Pacific: Brunei, Cambodia, China, China Hong Kong SAR*, Indonesia, Japan, Laos, Malaysia, Mongolia, North Korea, Philippines, Singapore, South Asia (Afghanistan, Bangladesh, India, Myanmar, Nepal, Pakistan, and Sri Lanka), South Korea, Taiwan, Thailand, Vietnam, Australia, New Zealand, Papua New Guinea, and Oceania, *Special Administrative Region.

- G8: France, Germany, Italy, Japan, the United Kingdom, the United States, Canada and Russia. 
- G20: France, Germany, Italy, Japan, United Kingdom, United States, Canada, Russia, Argentina, Australia, Brazil, China, India, Indonesia, Mexico, Saudi Arabia, South Africa, Republic of Korea, Turkey and the European Union.

- EU: Austria, Belgium, Bulgaria, Croatia, Republic of Cyprus, Czech Republic, Denmark, Estonia, Finland, France, Germany, Greece, Hungary, Ireland, Italy, Latvia, Lithuania, Luxembourg, Malta, The Netherlands, Poland, Portugal, Romania, Slovakia, Slovenia, Spain, and Sweden.

- OECD: Austria, Belgium, Czech Republic, Denmark, Estonia, Finland, France, Germany, Greece, Hungary, Iceland, Ireland, Italy, Latvia, Lithuania, Luxembourg, The Netherlands, Norway, Poland, Portugal, Slovak Republic, Slovenia, Spain, Sweden, Switzerland, and the United Kingdom.

\section{Appendix B. Reductions Allocated According to the Criteria HR Criterion and Reductions Allocated According to the Ability to Pay Criterion}

Table A1. Reductions Allocated According to the Criteria HR Criterion.

\begin{tabular}{|c|c|c|}
\hline Countries/Areas & $(\mathrm{Mt} \mathrm{CO} 2)$ & (\% of Total) \\
\hline US & 2765.83 & $23.37 \%$ \\
\hline China & 1835.75 & $15.51 \%$ \\
\hline Russian Federation & 565.24 & $4.78 \%$ \\
\hline Japan & 553.86 & $4.68 \%$ \\
\hline Germany & 496.61 & $4.20 \%$ \\
\hline India & 419.36 & $3.54 \%$ \\
\hline United Kingdom & 313.58 & $2.65 \%$ \\
\hline Canada & 244.23 & $2.06 \%$ \\
\hline France & 209.07 & $1.77 \%$ \\
\hline Italy & 202.06 & $1.71 \%$ \\
\hline Poland & 187.87 & $1.59 \%$ \\
\hline South Korea & 161.58 & $1.37 \%$ \\
\hline South Africa & 155.07 & $1.31 \%$ \\
\hline Australia & 149.96 & $1.27 \%$ \\
\hline Mexico & 148.45 & $1.25 \%$ \\
\hline Iran & 135.39 & $1.14 \%$ \\
\hline Ukraine & 133.69 & $1.13 \%$ \\
\hline Saudi Arabia & 129.27 & $1.09 \%$ \\
\hline Brazil & 128.03 & $1.08 \%$ \\
\hline Spain & 123.64 & $1.04 \%$ \\
\hline The Netherlands & 104.64 & $0.88 \%$ \\
\hline Indonesia & 103.78 & $0.88 \%$ \\
\hline Turkey & 81.85 & $0.69 \%$ \\
\hline Czech Republic & 81.21 & $0.69 \%$ \\
\hline Belgium & 69.73 & $0.59 \%$ \\
\hline Romania & 66.19 & $0.56 \%$ \\
\hline Thailand & 64.06 & $0.54 \%$ \\
\hline Argentina & 63.82 & $0.54 \%$ \\
\hline Kazakhstan & 60.18 & $0.51 \%$ \\
\hline Venezuela & 58.17 & $0.49 \%$ \\
\hline United Arab Emirates & 53.00 & $0.45 \%$ \\
\hline Egypt & 51.22 & $0.43 \%$ \\
\hline Malaysia & 48.71 & $0.41 \%$ \\
\hline Singapore & 44.95 & $0.38 \%$ \\
\hline Pakistan & 42.19 & $0.36 \%$ \\
\hline Greece & 38.06 & $0.32 \%$ \\
\hline Uzbekistan & 36.93 & $0.31 \%$ \\
\hline Sweden & 36.10 & $0.31 \%$ \\
\hline Hungary & 34.03 & $0.29 \%$ \\
\hline Bulgaria & 32.16 & $0.27 \%$ \\
\hline Algeria & 32.05 & $0.27 \%$ \\
\hline
\end{tabular}


Table A1. Cont.

\begin{tabular}{|c|c|c|}
\hline Countries/Areas & $(\mathrm{Mt} \mathrm{CO})_{2}$ & (\% of Total) \\
\hline Austria & 31.36 & $0.27 \%$ \\
\hline Denmark & 31.03 & $0.26 \%$ \\
\hline Finland & 28.46 & $0.24 \%$ \\
\hline Philippines & 26.85 & $0.23 \%$ \\
\hline Colombia & 26.21 & $0.22 \%$ \\
\hline Vietnam & 25.30 & $0.21 \%$ \\
\hline China Hong Kong SAR & 24.53 & $0.21 \%$ \\
\hline Kuwait & 24.07 & $0.20 \%$ \\
\hline Slovakia & 22.99 & $0.19 \%$ \\
\hline Chile & 22.55 & $0.19 \%$ \\
\hline Israel & 22.35 & $0.19 \%$ \\
\hline Belarus & 22.13 & $0.19 \%$ \\
\hline Switzerland & 21.89 & $0.18 \%$ \\
\hline Portugal & 21.11 & $0.18 \%$ \\
\hline Ireland & 17.72 & $0.15 \%$ \\
\hline Norway & 16.94 & $0.14 \%$ \\
\hline Turkmenistan & 15.69 & $0.13 \%$ \\
\hline Qatar & 14.45 & $0.12 \%$ \\
\hline New Zealand & 14.19 & $0.12 \%$ \\
\hline Peru & 13.25 & $0.11 \%$ \\
\hline Azerbaijan & 11.80 & $0.10 \%$ \\
\hline Bangladesh & 11.69 & $0.10 \%$ \\
\hline Ecuador & 8.54 & $0.07 \%$ \\
\hline Trinidad \& Tobago & 7.81 & $0.07 \%$ \\
\hline Lithuania & 5.98 & $0.05 \%$ \\
\hline OECD & 6272.30 & $53.00 \%$ \\
\hline UE & 2184.98 & $18.46 \%$ \\
\hline No OECD & 5561.53 & $47.00 \%$ \\
\hline Total top 10 & 7605.59 & $64.27 \%$ \\
\hline Total considered & $10,750.46$ & $90.85 \%$ \\
\hline Rest & 1083.36 & $9.15 \%$ \\
\hline Total World & $11,833.82$ & $100.00 \%$ \\
\hline
\end{tabular}

Source: Author, using BP data [50].

Table A2. Reductions Allocated According to the Ability to Pay Criterion.

\begin{tabular}{|c|c|c|}
\hline Countries/Areas & $(\mathrm{Mt} \mathrm{CO})_{2}$ & (\% of Total) \\
\hline US & 2905.80 & $24.56 \%$ \\
\hline China & 1747.30 & $14.77 \%$ \\
\hline Japan & 771.28 & $6.52 \%$ \\
\hline Germany & 542.61 & $4.59 \%$ \\
\hline United Kingdom & 413.13 & $3.49 \%$ \\
\hline France & 384.60 & $3.25 \%$ \\
\hline India & 353.20 & $2.98 \%$ \\
\hline Italy & 290.03 & $2.45 \%$ \\
\hline Brazil & 280.24 & $2.37 \%$ \\
\hline Canada & 238.67 & $2.02 \%$ \\
\hline South Korea & 220.11 & $1.86 \%$ \\
\hline Russian Federation & 200.20 & $1.69 \%$ \\
\hline Spain & 192.89 & $1.63 \%$ \\
\hline Australia & 187.95 & $1.59 \%$ \\
\hline Mexico & 163.34 & $1.38 \%$ \\
\hline Indonesia & 145.45 & $1.23 \%$ \\
\hline Turkey & 134.91 & $1.14 \%$ \\
\hline
\end{tabular}


Table A2. Cont.

\begin{tabular}{|c|c|c|}
\hline Countries/Areas & $(\mathrm{Mt} \mathrm{CO})_{2}$ & (\% of Total) \\
\hline The Netherlands & 121.26 & $1.02 \%$ \\
\hline Switzerland & 104.14 & $0.88 \%$ \\
\hline Saudi Arabia & 100.86 & $0.85 \%$ \\
\hline Argentina & 85.11 & $0.72 \%$ \\
\hline Sweden & 80.47 & $0.68 \%$ \\
\hline Poland & 73.54 & $0.62 \%$ \\
\hline Belgium & 73.37 & $0.62 \%$ \\
\hline Venezuela & 72.21 & $0.61 \%$ \\
\hline Iran & 65.37 & $0.55 \%$ \\
\hline Thailand & 63.50 & $0.54 \%$ \\
\hline Austria & 60.35 & $0.51 \%$ \\
\hline Norway & 57.90 & $0.49 \%$ \\
\hline United Arab Emirates & 54.41 & $0.46 \%$ \\
\hline Egypt & 51.92 & $0.44 \%$ \\
\hline Israel & 49.70 & $0.42 \%$ \\
\hline China Hong Kong SAR & 49.70 & $0.42 \%$ \\
\hline Singapore & 48.52 & $0.41 \%$ \\
\hline Denmark & 47.88 & $0.40 \%$ \\
\hline Ireland & 47.34 & $0.40 \%$ \\
\hline Philippines & 47.34 & $0.40 \%$ \\
\hline Malaysia & 46.27 & $0.39 \%$ \\
\hline South Africa & 46.15 & $0.39 \%$ \\
\hline Colombia & 44.07 & $0.37 \%$ \\
\hline Pakistan & 43.52 & $0.37 \%$ \\
\hline Chile & 39.05 & $0.33 \%$ \\
\hline Finland & 36.68 & $0.31 \%$ \\
\hline Bangladesh & 34.55 & $0.29 \%$ \\
\hline Vietnam & 32.03 & $0.27 \%$ \\
\hline Portugal & 31.95 & $0.27 \%$ \\
\hline Czech Republic & 30.77 & $0.26 \%$ \\
\hline Peru & 29.99 & $0.25 \%$ \\
\hline Greece & 29.58 & $0.25 \%$ \\
\hline New Zealand & 29.58 & $0.25 \%$ \\
\hline Romania & 29.27 & $0.25 \%$ \\
\hline Algeria & 24.81 & $0.21 \%$ \\
\hline Qatar & 23.79 & $0.20 \%$ \\
\hline Kazakhstan & 21.42 & $0.18 \%$ \\
\hline Hungary & 20.12 & $0.17 \%$ \\
\hline Kuwait & 17.30 & $0.15 \%$ \\
\hline Ecuador & 15.38 & $0.13 \%$ \\
\hline Ukraine & 14.55 & $0.12 \%$ \\
\hline Slovakia & 14.20 & $0.12 \%$ \\
\hline Uzbekistan & 10.49 & $0.09 \%$ \\
\hline Bulgaria & 8.28 & $0.07 \%$ \\
\hline Belarus & 7.10 & $0.06 \%$ \\
\hline Lithuania & 7.10 & $0.06 \%$ \\
\hline Azerbaijan & 5.91 & $0.05 \%$ \\
\hline Turkmenistan & 5.64 & $0.05 \%$ \\
\hline Trinidad \& Tobago & 3.42 & $0.03 \%$ \\
\hline OECD & 7426.95 & $62.76 \%$ \\
\hline UE & 2570.31 & $21.72 \%$ \\
\hline No OECD & 4406.87 & $37.24 \%$ \\
\hline Total top 10 & 7926.86 & $66.98 \%$ \\
\hline Total considered & $11,229.57$ & $94.89 \%$ \\
\hline Rest & 604,25 & $5.11 \%$ \\
\hline Total World & $11,833.82$ & $100.00 \%$ \\
\hline
\end{tabular}




\section{References}

1. Grubler, A. Energy transitions research: Insights and cautionary tales. Energy Policy 2012, 50, 8-16. [CrossRef]

2. Carpintero, Ó. y Riechmann, Pensar la transición: Enseñanzas y estrategias económico-ecológicas. Revista de Economía Crítica 2013, 16, 45-107.

3. Hancock, K.J.; Vivoda, V. International political economy: A field born of the OPEC crisis returns to its energy roots. Energy Res. Soc. Sci. 2014, 1, 206-216. [CrossRef]

4. Pan, X.; Teng, F.; Tian, Y.; Wang, G. Countries' emission allowances towards the low-carbon world: A consistent study. Appl. Energy 2015, 155, 218-228. [CrossRef]

5. Bataille, C.; Åhman, M.; Neuhoff, K.; Nilsson, L.J.; Fischedick, M.; Lechtenböhmer, S.; Solano-Rodriquez, B.; Denis-Ryan, A.; Stiebert, S.; Waisman, H.; et al. A review of technology and policy deep decarbonization pathway options for making energy-intensive industry production consistent with the Paris Agreement. J. Clean. Prod. 2018, 187, 960-973. [CrossRef]

6. Bel, G.; Teixidó, J.J. The political economy of the Paris Agreement: Income inequality and climate policy. J. Clean. Prod. 2020, 258, 121002. [CrossRef]

7. Acar, S.; Söderholm, P.; Brännlund, R. Convergence of per capita carbon dioxide emissions: Implications and meta-analysis. Clim. Policy 2018, 18, 512-525. [CrossRef]

8. Zhong, Z.; Jiang, L.; Zhou, P. Transnational transfer of carbon emissions embodied in trade: Characteristics and determinants from a spatial perspective. Energy 2018, 147, 858-875. [CrossRef]

9. Falkner, R. The Paris Agreement and the new logic of international climate politics. Int. Aff. 2016, 92, 1107-1125. [CrossRef]

10. Nieto, J.; Carpintero, Ó.; Miguel, L.J. Less than $2{ }^{\circ} \mathrm{C}$ ? An Economic-Environmental Evaluation of the Paris Agreement. Ecol. Econ. 2018, 146, 69-84. [CrossRef]

11. Viola, E. The Structural Limits of the Paris Agreement and the Need of a Global Coalition for Deep de-Carbonization. In Will the Paris Agreement Save the World? An Analysis and Critique of the Governance Roadmap Set out in COP21; Norwegian Academy on Global Governance: Oslo, Norway, 2016; pp. 47-56.

12. Chaudhry, S.M.; Ahmed, R.; Shafiullah, M.; Duc Huynh, T.L. The impact of carbon emissions on country risk: Evidence from the G7 economies. J. Environ. Manage. 2020, 265, 110533. [CrossRef] [PubMed]

13. Gignac, R.; Matthews, H.D. Allocating a 2 C cumulative carbon budget to countries. Environ. Res. Lett. 2015, 10, 075004. [CrossRef]

14. Xunzhang, P.; Wenying, C.; Clarke, L.E.; Lining, W.; Guannan, L. China's energy system transformation towards the $2{ }^{\circ} \mathrm{C}$ goal: Implications of different effort-sharing principles. Energy Policy 2017, 103, 116-126. [CrossRef]

15. den Elzen, M.G.J. Exploring Climate Regimes for Differentiation of Future Commitments to Stabilise Greenhouse Gas Concentrations. Integr. Assess. 2002, 3, 343-359. [CrossRef]

16. Den Elzen, M.G.J.; Lucas, P.L. The FAIR model: A tool to analyse environmental and costs implications of regimes of future commitments. Environ. Model. Assess. 2005, 10, 115-134. [CrossRef]

17. Ghersi, F.; Hourcade, J.C.; Criqui, P. Viable responses to the equity-responsibility dilemma: A consequentialist view. Clim. Policy 2003, 3. [CrossRef]

18. Torvanger, A.; Godal, O. An evaluation of pre-kyoto differentiation proposals for national greenhouse gas abatement targets. Int. Environ. Agreem. Polit. Law Econ. 2003, 4, 65-91. [CrossRef]

19. Hof, A.F.; Den Elzen, M.G.J. The effect of different historical emissions datasets on emission targets of the sectoral mitigation approach Triptych. Clim. Policy 2010, 10, 684-704. [CrossRef]

20. Ringius, L.; Torvanger, A.; Holtsmark, B. Can multi-criteria rules fairly distribute climate burdens? OECD results from three burden sharing rules. Energy Policy 1998, 26, 777-793. [CrossRef]

21. Winkler, H.; Spalding-Fecher, R.; Tyani, L. Comparing developing countries under potential carbon allocation schemes. Clim. Policy 2002, 2, 303-318. [CrossRef]

22. Pettersson, F.; Maddison, D.; Acar, S.; Söderholm, P. Convergence of carbon dioxide emissions: A review of the literature. Int. Rev. Environ. Resour. Econ. 2013, 7, 141-178. [CrossRef]

23. Zhou, P.; Wang, M. Carbon dioxide emissions allocation: A review. Ecol. Econ. 2016, 125, 47-59. [CrossRef]

24. Payne, J.E. The convergence of carbon dioxide emissions: A survey of the empirical literature. J. Econ. Stud. 2020. [CrossRef] 
25. Duro, J.A.; Giménez-Gómez, J.M.; Vilella, C. The allocation of $\mathrm{CO}_{2}$ emissions as a claims problem. Energy Econ. 2020, 86, 104652. [CrossRef]

26. Mackenzie, I.A.; Hanley, N.; Kornienko, T. The optimal initial allocation of pollution permits: A relative performance approach. Environ. Resour. Econ. 2008, 39, 265-282. [CrossRef]

27. MacKenzie, I.A.; Hanley, N.; Kornienko, T. Using contests to allocate pollution rights. Energy Policy 2009, 37, 2798-2806. [CrossRef]

28. Liao, Z.; Zhu, X.; Shi, J. Case study on initial allocation of Shanghai carbon emission trading based on Shapley value. J. Clean. Prod. 2015, 103, 338-344. [CrossRef]

29. Gutiérrez, E.; Llorca, N.; Sánchez-Soriano, J.; Mosquera, M. Sustainable allocation of greenhouse gas emission permits for firms with Leontief technologies. Eur. J. Oper. Res. 2018, 269, 5-15. [CrossRef]

30. Lozano, S.; Villa, G.; Brännlund, R. Centralised reallocation of emission permits using DEA. Eur. J. Oper. Res. 2009, 193, 752-760. [CrossRef]

31. Sun, J.; Wu, J.; Liang, L.; Zhong, R.Y.; Huang, G.Q. Allocation of emission permits using DEA: Centralised and individual points of view. Int. J. Prod. Res. 2014, 52, 419-435. [CrossRef]

32. Lee, C.-Y.; Wang, K.; Sun, W. Allocation of Emissions Permit for China's Iron and Steel Industry in an Imperfectly Competitive Market: A Nash Equilibrium DEA Method. IEEE Trans. Eng. Manag. 2020, 1-14. [CrossRef]

33. Ichisugi, Y.; Masui, T.; Karkour, S.; Itsubo, N. Projection of National Carbon Footprint in Japan with Integration of LCA and IAMs. Sustainability 2019, 11, 6875. [CrossRef]

34. Ridgley, M.A. Fair sharing of greenhouse gas burdens. Energy Policy 1996, 24, 517-529. [CrossRef]

35. Chakravarty, S.; Chikkatur, A.; De Coninck, H.; Pacala, S.; Socolow, R.; Tavoni, M. Sharing global CO 2 emission reductions among one billion high emitters. Proc. Natl. Acad. Sci. USA 2009, 106, 11884-11888. [CrossRef]

36. Pan, X.; Teng, F.; Wang, G. Sharing emission space at an equitable basis: Allocation scheme based on the equal cumulative emission per capita principle. Appl. Energy 2014, 113, 1810-1818. [CrossRef]

37. Rose, A.; Zhang, Z.X. Interregional Burden-Sharing of Greenhouse Gas Mitigation in the United States. SSRN Electron. J. 2005. [CrossRef]

38. Zhou, P.; Zhang, L.; Zhou, D.Q.; Xia, W.J. Modeling economic performance of interprovincial $\mathrm{CO}_{2}$ emission reduction quota trading in China. Appl. Energy 2013, 112, 1518-1528. [CrossRef]

39. Yang, B.; Liu, C.; Su, Y.; Jing, X. The allocation of carbon intensity reduction target by 2020 among industrial sectors in China. Sustainability 2017, 9, 148. [CrossRef]

40. Zhang, J.; Jiang, H.; Liu, G.; Zeng, W. A study on the contribution of industrial restructuring to reduction of carbon emissions in China during the five Five-Year Plan periods. J. Clean. Prod. 2018, 176, 629-635. [CrossRef]

41. Zhou, X.; Guan, X.; Zhang, M.; Zhou, Y.; Zhou, M. Allocation and simulation study of carbon emission quotas among China's provinces in 2020. Environ. Sci. Pollut. Res. 2017, 24, 7088-7113. [CrossRef]

42. Bian, Y.; Yu, Z.; Zeng, X.; Feng, J.; He, C. Achieving China's long-term carbon emission abatement targets: A perspective from regional disparity. Sustainability 2018, 10, 4244. [CrossRef]

43. Zhao, R.; Min, N.; Geng, Y.; He, Y. Allocation of carbon emissions among industries/sectors: An emissions intensity reduction constrained approach. J. Clean. Prod. 2017, 142, 3083-3094. [CrossRef]

44. Baghdadi, L.; Martinez-Zarzoso, I.; Zitouna, H. Are RTA agreements with environmental provisions reducing emissions? J. Int. Econ. 2013, 90, 378-390. [CrossRef]

45. Apergis, N.; Payne, J.E.; Rayos-Velazquez, M. Carbon Dioxide Emissions Intensity Convergence: Evidence From Central American Countries. Front. Energy Res. 2020, 7. [CrossRef]

46. Apergis, N.; Payne, J.E. NAFTA and the convergence of $\mathrm{CO}_{2}$ emissions intensity and its determinants. Int. Econ. 2020, 161, 1-9. [CrossRef]

47. Ma, Z.; Cai, S.; Ye, W.; Gu, A. Linking Emissions Trading Schemes: Economic Valuation of a Joint China-Japan-Korea Carbon Market. Sustainability 2019, 11, 5303. [CrossRef]

48. Martin, R.; Muuls, M.; Wagner, U.J. The Impact of the European Union Emissions Trading Scheme on Regulated Firms: What Is the Evidence after Ten Years? Rev. Environ. Econ. Policy 2016, 10, 129-148. [CrossRef]

49. Oestreich, A.M.; Tsiakas, I. Carbon emissions and stock returns: Evidence from the EU Emissions Trading Scheme. J. Bank. Financ. 2015, 58, 294-308. [CrossRef] 
50. Gomes, E.G.; Lins, M.P.E. Modelling undesirable outputs with zero sum gains data envelopment analysis models. J. Oper. Res. Soc. 2008, 59, 616-623. [CrossRef]

51. Chang, M.-C. Carbon Emission Allocation and Efficiency of EU Countries *. Mod. Econ. 2012, 3, $590-596$. [CrossRef]

52. Cucchiella, F.; D'Adamo, I.; Gastaldi, M.; Miliacca, M. Efficiency and allocation of emission allowances and energy consumption over more sustainable European economies. J. Clean. Prod. 2018, 182, 805-817. [CrossRef]

53. Apergis, N.; Payne, J.E. Per capita carbon dioxide emissions across U.S. states by sector and fossil fuel source: Evidence from club convergence tests. Energy Econ. 2017, 63, 365-372. [CrossRef]

54. Apergis, N.; Payne, J.E.; Topcu, M. Some empirics on the convergence of carbon dioxide emissions intensity across US states. Energy Sources, Part B Econ. Plan. Policy 2017, 12, 831-837. [CrossRef]

55. Sahu, S. Emissions Sharing Observations from a Diverse Range of Countries. Sustainability 2019, 11, 4013. [CrossRef]

56. Collado, J.R.N.; Wang, H.H.; Tsai, T.Y. Urban informality in the Paris climate agreement: Content analysis of the nationally determined contributions of highly urbanized developing countries. Sustain. 2019, 11, 5228. [CrossRef]

57. Pérez, F.; Blancas, F.J.; González, M.; Guerrero, F.M.; Lozano, M.; Ruiz, M. Análisis, diseño y comparación de indicadores sintéticos. In Proceedings of the XVI Jornadas ASEPUMA-IV Encuentro Internacional, Cartagena, Colombia, 18-19 September 2008; Volume 16, p. 1.

58. Van Ruijven, B.J.; Weitzel, M.; den Elzen, M.G.J.; Hof, A.F.; van Vuuren, D.P.; Peterson, S.; Narita, D. Emission allowances and mitigation costs of China and India resulting from different effort-sharing approaches. Energy Policy 2012, 46, 116-134. [CrossRef]

59. British Petroleum. BP Statistical Review of World Energy_Data Workbook; BP: London, UK, 2017.

60. World Bank. World Indicators Database; World Bank: Washington, DC, USA, 2018.

61. Friedlingstein, P.; Jones, M.; O'sullivan, M. Global Carbon Budget 2019. Earth Syst. Sci. Data 2019, 11, 1783-1838. [CrossRef]

62. Zhang, Y.X.; Chao, Q.C.; Zheng, Q.H.; Huang, L. The withdrawal of the U.S. from the Paris Agreement and its impact on global climate change governance. Adv. Clim. Chang. Res. 2017, 8, 213-219. [CrossRef]

63. Höhne, N.; Kuramochi, T.; Warnecke, C.; Röser, F.; Fekete, H.; Hagemann, M.; Day, T.; Tewari, R.; Kurdziel, M.; Sterl, S.; et al. The Paris Agreement: Resolving the inconsistency between global goals and national contributions. Clim. Policy 2017, 17, 16-32. [CrossRef]

64. Kolk, A.; Levy, D. Winds of Change: Corporate Strategy, Climate change and Oil Multinationals. Eur. Manag. J. 2001, 19, 501-509. [CrossRef]

65. van den Hove, S.; Le Menestrel, M.; de Bettignies, H.C. The oil industry and climate change: Strategies and ethical dilemmas. Clim. Policy 2002, 2, 3-18. [CrossRef]

66. McGlade, C.; Ekins, P. The geographical distribution of fossil fuels unused when limiting global warming to $2{ }^{\circ} \mathrm{C}$. Nature 2015, 517, 187-190. [CrossRef] [PubMed]

67. Gadre, R.; Anandarajah, G. Assessing the evolution of India's power sector to 2050 under different $\mathrm{CO}_{2}$ emissions rights allocation schemes. Energy Sustain. Dev. 2019, 50, 126-138. [CrossRef]

(C) 2020 by the authors. Licensee MDPI, Basel, Switzerland. This article is an open access article distributed under the terms and conditions of the Creative Commons Attribution (CC BY) license (http://creativecommons.org/licenses/by/4.0/). 